\title{
Rates and regimes of photochemical ozone production over Central East China in June 2006: a box model analysis using comprehensive measurements of ozone precursors
}

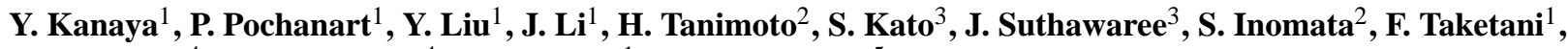 \\ K. Okuzawa ${ }^{4}$, K. Kawamura ${ }^{4}$, H. Akimoto ${ }^{1}$, and Z. F. Wang ${ }^{5}$ \\ ${ }^{1}$ Research Institute for Global Change, Japan Agency for Marine-Earth Science and Technology, Yokohama, Japan \\ ${ }^{2}$ National Institute for Environmental Studies, Tsukuba, Japan \\ ${ }^{3}$ Tokyo Metropolitan University, Hachioji, Japan \\ ${ }^{4}$ Institute of Low Temperature Science, Hokkaido University, Sapporo, Japan \\ ${ }^{5}$ LAPC/NZC, Institute of Atmospheric Physics, Chinese Academy of Sciences, Beijing, China
}

Received: 17 May 2009 - Published in Atmos. Chem. Phys. Discuss.: 9 June 2009

Revised: 5 September 2009 - Accepted: 22 September 2009 - Published: 16 October 2009

\begin{abstract}
An observation-based box model approach was undertaken to estimate concentrations of $\mathrm{OH}, \mathrm{HO}_{2}$, and $\mathrm{RO}_{2}$ radicals and the net photochemical production rate of ozone at the top of Mount Tai, located in the middle of Central East China, in June 2006. The model calculation was constrained by the measurements of $\mathrm{O}_{3}, \mathrm{H}_{2} \mathrm{O}, \mathrm{CO}, \mathrm{NO}, \mathrm{NO}_{2}$, hydrocarbon, $\mathrm{HCHO}$, and $\mathrm{CH}_{3} \mathrm{CHO}$ concentrations, and temperature and $J$ values. The net production rate of ozone was estimated to be $6.4 \mathrm{ppbh}^{-1}$ as a 6-h average (09:00-15:00 CST), suggesting $58 \pm 37 \mathrm{ppb}$ of ozone is produced in one day. Thus the daytime buildup of ozone recorded at the mountain top as $\sim 23 \mathrm{ppb}$ on average is likely affected by in situ photochemistry as well as by the upward transport of polluted air mass in the daytime. On days with high ozone concentrations (hourly values exceeding $100 \mathrm{ppb}$ at least once), in situ photochemistry was more active than it was on low ozone days, suggesting that in situ photochemistry is an important factor controlling ozone concentrations. Sensitivity model runs for which different $\mathrm{NO}_{\mathrm{x}}$ and hydrocarbon concentrations were assumed suggested that the ozone production occurred normally under $\mathrm{NO}_{\mathrm{x}}$-limited conditions, with some exceptional periods (under volatile-organic-compound-limited conditions) in which there was fresh pollution. We also examined the possible influence of the heterogeneous loss of gaseous $\mathrm{HO}_{2}$ radicals in contact with aerosol particle surfaces on the rate and regimes of ozone production.
\end{abstract}

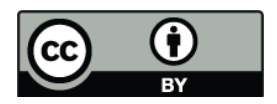

Correspondence to: Y. Kanaya (yugo@jamstec.go.jp)

\section{Introduction}

Central East China (CEC) is regarded as one of the regions in the world where tropospheric ozone is present at high concentrations. Pochanart et al. (2009) revealed the seasonal variation in ozone concentrations over CEC from observation. They found that at the top of Mount Tai $\left(36.26^{\circ} \mathrm{N}\right.$, $117.11^{\circ} \mathrm{E}, 1534 \mathrm{~m}$ a.s.l., Shandong Province of the People's Republic of China) located in the middle of CEC, monthly averaged ozone concentrations regularly peak in June at $\sim 80 \mathrm{ppbv}$, with highest hourly values exceeding $120 \mathrm{ppbv}$ in each year of 2004-2006. Considering that the site is not directly affected by plumes from large cities, a geographically wide area (with a scale of several hundred kilometers) is likely covered by air masses containing high concentrations of ozone. Zhu et al. (2004) indicated in their regional modeling study that a zonal band (between 35 and $40^{\circ} \mathrm{N}$ ) of high ozone concentration ( $>70 \mathrm{ppb}$ ) emerged from the western boundary $\left(70^{\circ} \mathrm{E}\right)$ of their model domain to $130^{\circ} \mathrm{E}$ in June, the latitudinal location of which was affected by seasonal transition associated with the Asian monsoon system. The regionally high ozone burden in this region is of interest from the viewpoints of the greenhouse effect, health effects, and agricultural damage.

The primary cause for the high ozone concentrations over this region would be photochemical production. Wang et al. (2006) simulated an episode of high ozone concentrations (around $110 \mathrm{ppbv}$ ) observed at Mt. Tai on 24 and 25 May 2004 with the Nested Air Quality Prediction Modeling System and found that the modeled ozone concentrations

Published by Copernicus Publications on behalf of the European Geosciences Union. 
at Mt. Tai had a large (20-50\%) sensitivity to emissions in the Yangtze Delta region, suggesting that the photochemistry during the travel of the air mass from that region was important. Using a similar model, Li et al. (2007) calculated that photochemical production is the dominant term for the time derivative of ozone concentration for the grid surrounding Mount Tai station (surface area of $400 \times 400 \mathrm{~km}$ with a $0-2.5 \mathrm{~km}$ altitude range) in June. However, an in situ production rate of ozone that is representative over this region has not yet been quantified on the basis of the observed concentrations of ozone precursors $\left(\mathrm{NO}_{\mathrm{x}}, \mathrm{CO}\right.$, and hydrocarbons) and relevant parameters ( $J$ values, temperature, and humidity).

Knowledge of the ozone production regime $\left(\mathrm{NO}_{\mathrm{x}}\right.$-limited vs. volatile organic compound (VOC)-limited) over this region is essential for the establishment of controlling strategies of ozone concentrations. These concentrations are expected to increase at least in the coming decade over CEC (e.g., Yamaji et al., 2008) owing to fast economic growth and the associated increase in the emission rates of ozone precursors (Ohara et al., 2007). In past modeling studies, Carmichael et al. (2003a) suggested that ozone production in the north/central region of CEC (north of $30-35^{\circ} \mathrm{N}$ ) is VOClimited at $440 \mathrm{~m}$ altitude in March, while it is $\mathrm{NO}_{\mathrm{x}}$-limited south of $\sim 30-35^{\circ} \mathrm{N}$. Luo et al. (2000) similarly suggested that VOC limitation generally applies in late October-early November north of the Yangtze Delta. However, the precursor concentrations in the model simulations have not been validated through observations, making the analysis susceptible to large uncertainty in the emission rates of the precursors in this area (Streets et al., 2003). Martin et al. (2004) found that $\mathrm{HCHO} / \mathrm{NO}_{2}$ column concentration ratios derived from Global Ozone Monitoring Experiment satellite data are greater than 1 during summer over eastern China, indicating $\mathrm{NO}_{\mathrm{x}}$-sensitive conditions. In this case, however, the observed column density of $\mathrm{HCHO}$ was used as a proxy to infer the VOC concentrations, which have not been observed directly. Considering that the regimes could change with seasons owing to variations in the production rates of radicals that mediate ozone production and in the amount of biogenic hydrocarbons, knowledge of the regimes over this region in this heavily polluted month is currently very limited.

In June 2006, we conducted the Mount Tai Experiment 2006 field campaign at the top of Mount Tai and measured ozone, its precursors $\left(\mathrm{CO}, \mathrm{NO}, \mathrm{NO}_{2}\right.$, hydrocarbons, $\mathrm{HCHO}$, and $\mathrm{CH}_{3} \mathrm{CHO}$ ), and relevant meteorological/radiative parameters ( $J$ values, temperature, and humidity). Using the observed concentrations and parameters as input to a photochemical box model employing a tropospheric chemistry mechanism, concentrations of $\mathrm{OH}, \mathrm{HO}_{2}$, and $\mathrm{RO}_{2}$ (organic peroxy) radicals were calculated first and then net in situ photochemical production rates of ozone were estimated on the basis of the radical concentrations. We also performed sensitivity model runs where different $\mathrm{NO}_{\mathrm{x}}$ or VOC concentrations were assumed to study the ozone production regimes at the location. Another set of model runs including heterogeneous loss of $\mathrm{HO}_{2}$ on aerosol surfaces was executed to estimate its impact on the ozone production rate and regimes.

\section{Experimental}

$\mathrm{O}_{3}$ and $\mathrm{CO}$ were measured by commercially available instruments based on ultraviolet and nondispersive infrared absorption (Thermo, models 49C and 48C) on a year-round basis (Pochanart et al., 2009). Purified air produced by a zero air generator (Thermo, model 111) was periodically introduced to the CO-measuring instrument to determine the zero level. $\mathrm{NO}, \mathrm{NO}_{\mathrm{x}}$, and $\mathrm{NO}_{\mathrm{y}}$ were sequentially detected by a customized instrument based on a commercially available instrument (Thermo, model 42CTL). An air sample for this instrument passed through one of three gas lines: a line with a molybdenum converter, a line with a blue light (light emitting diode) converter (Droplet Measurement Technology, USA), and a line without converters. The two converters were located at the entrance of the sampling tube, such that $\mathrm{NO}_{\mathrm{y}}$ and $\mathrm{NO}_{2}$ are converted to $\mathrm{NO}$, a relatively inert molecule, at an early part of the inlet line with minimum loss. The conversion efficiency of $\mathrm{NO}_{2}$ to $\mathrm{NO}$ by the blue light converter during the campaign was $50 \%$. The sensitivity to NO was determined against a premixed gas of $\mathrm{NO} / \mathrm{N}_{2}$ (2.004 ppmv, Taiyo Nippon Sanso Corporation). The sensitivity agreed with that determined with a cylinder with NIST-traceability to within $2 \%$. The detection limit of the instrument is specified to be $0.1 \mathrm{ppbv}$ for $\mathrm{NO}$ and $0.2 \mathrm{ppbv}$ for $\mathrm{NO}_{2}$ and $\mathrm{NO}_{\mathrm{y}}$. VOC measurements were made with canister samplings (performed on 30 occasions during the campaign) followed by analysis using gas chromatography-flame ionization detection (GC-FID) and gas chromatography-mass spectrometry (GC-MS) (Suthawaree et al., 2009). The sampling was made typically once per day (typically at 14:40 CST), with a sampling duration of 2 min. Proton-transfer reaction-mass spectrometry (PTR-MS) was conducted in the latter part of the campaign (13-30 June) (Inomata et al., 2008, 2009). We used concentrations of $\mathrm{HCHO}, \mathrm{CH}_{3} \mathrm{OH}, \mathrm{CH}_{3} \mathrm{CHO}$, isoprene, methylvinylketone (MVK) + methacrolein (MACR), methylethylketone (MEK), benzene, and $\Sigma$-monoterpene measured by PTR-MS for analysis in this paper. The detection limits were estimated to be $0.37-0.83,0.74,0.29$ $0.35,0.28,0.1,0.08,0.13$, and $0.06 \mathrm{ppbv}$, respectively. It was assumed that the signal corresponding to $\mathrm{m} / \mathrm{z} 71$ in the PTR-MS was from MACR and MVK with 50\% contributions. The spectral actinic flux was measured by a singlemonochromator/photodiode array instrument (Meteorologie Consult Inc.) covering a wavelength region from 274 to $698 \mathrm{~nm}$. The instrument was calibrated against a standard halogen lamp. The uncertainty in $J\left(\mathrm{O}^{1} D\right)$ for a similar instrument has been estimated to be $14 \%$ (Heard et al., 2006). 
Table 1. Hydrocarbons taken into account in the model calculation and their categorization in the RACM.

\begin{tabular}{|c|c|c|c|c|}
\hline \multirow[t]{2}{*}{ RACM category } & \multicolumn{4}{|c|}{ Hydrocarbons taken into account in the model calculation } \\
\hline & $\begin{array}{l}\text { Measured by GC, taken into } \\
\text { account in the model by re- } \\
\text { lationship with } \mathrm{CO}\end{array}$ & $\begin{array}{l}\text { Measured by GC, taken into } \\
\text { account in the model at } \\
\text { campaign averages }\end{array}$ & $\begin{array}{l}\text { Measured by PTR- } \\
\text { MS, taken into ac- } \\
\text { count in the model by } \\
\text { relationship with CO }\end{array}$ & $\begin{array}{l}\text { Biogenic species mea- } \\
\text { sured by PTR-MS, av- } \\
\text { eraged diurnal vari- } \\
\text { ations used in the } \\
\text { model }\end{array}$ \\
\hline ETH & ethane & & & \\
\hline $\mathrm{HC} 3$ & $\begin{array}{l}\text { propane, } \\
\text { i-butane, } \\
\text { n-butane, } \\
\text { acetylene }\end{array}$ & 2,2-dimethylbutane & methanol & \\
\hline $\mathrm{HC} 5$ & $\begin{array}{l}\text { i-pentane, } \\
\text { n-pentane, } \\
\text { 2-methylpentane, } \\
\text { 3-methylpentane, } \\
\text { n-hexane }\end{array}$ & $\begin{array}{l}\text { cyclopentane, } \\
\text { 2,3-dimethylbutane, } \\
\text { 2,4-dimethylpentane, } \\
\text { 2,2,4-trimethylpentane }\end{array}$ & & \\
\hline $\mathrm{HC} 8$ & $\begin{array}{l}\text { methylcyclopentane, } \\
\text { cyclohexane, } \\
\text { 2-methylhexane, } \\
\text { n-heptane, } \\
\text { methylcyclohexane, } \\
\text { n-octane, } \\
\text { n-nonane }\end{array}$ & $\begin{array}{l}\text { 2,3-dimethylpentane, } \\
\text { 3-methylhexane, } \\
\text { 2-methylheptane, } \\
\text { 3-methylheptane }\end{array}$ & & \\
\hline ETE & ethene & & & \\
\hline OLT & $\begin{array}{l}\text { propene, } \\
\text { 1-butene }\end{array}$ & $\begin{array}{l}\text { 3-methyl-1-butene, } \\
\text { 1-pentene, } \\
\text { styrene }\end{array}$ & & \\
\hline OLI & & $\begin{array}{l}\text { trans-2-butene, } \\
\text { cis-2-butene, } \\
\text { trans-2-pentene, } \\
\text { cis-2-pentene, } \\
\text { 2-methyl-2-butene, } \\
\text { cyclopentene, } \\
\text { trans-2-hexene, } \\
\text { cis-2-hexene }\end{array}$ & & \\
\hline DIEN & 1,3-butadiene & & & \\
\hline ISO & & & & isoprene \\
\hline API & & & & $\begin{array}{l}\text { alpha-pinene, } \\
\text { beta-pinene, } \\
\text { camphene }\end{array}$ \\
\hline LIM & & & & limonene \\
\hline TOL & $\begin{array}{l}\text { toluene, } \\
\text { ethylbenzene }\end{array}$ & $\begin{array}{l}\text { iso-propylbenzene, } \\
\text { styrene }\end{array}$ & benzene & \\
\hline XYL & $\begin{array}{l}\text { p,m-xylene, } \\
\text { o-xylene }\end{array}$ & & & \\
\hline $\mathrm{HCHO}$ & & & $\mathrm{HCHO}$ & \\
\hline ALD & & & acetaldehyde & \\
\hline MACR & & & $\begin{array}{l}\text { acetone, } \\
\text { MVK, } \\
\text { MEK } \\
\text { methacrolein }\end{array}$ & \\
\hline
\end{tabular}



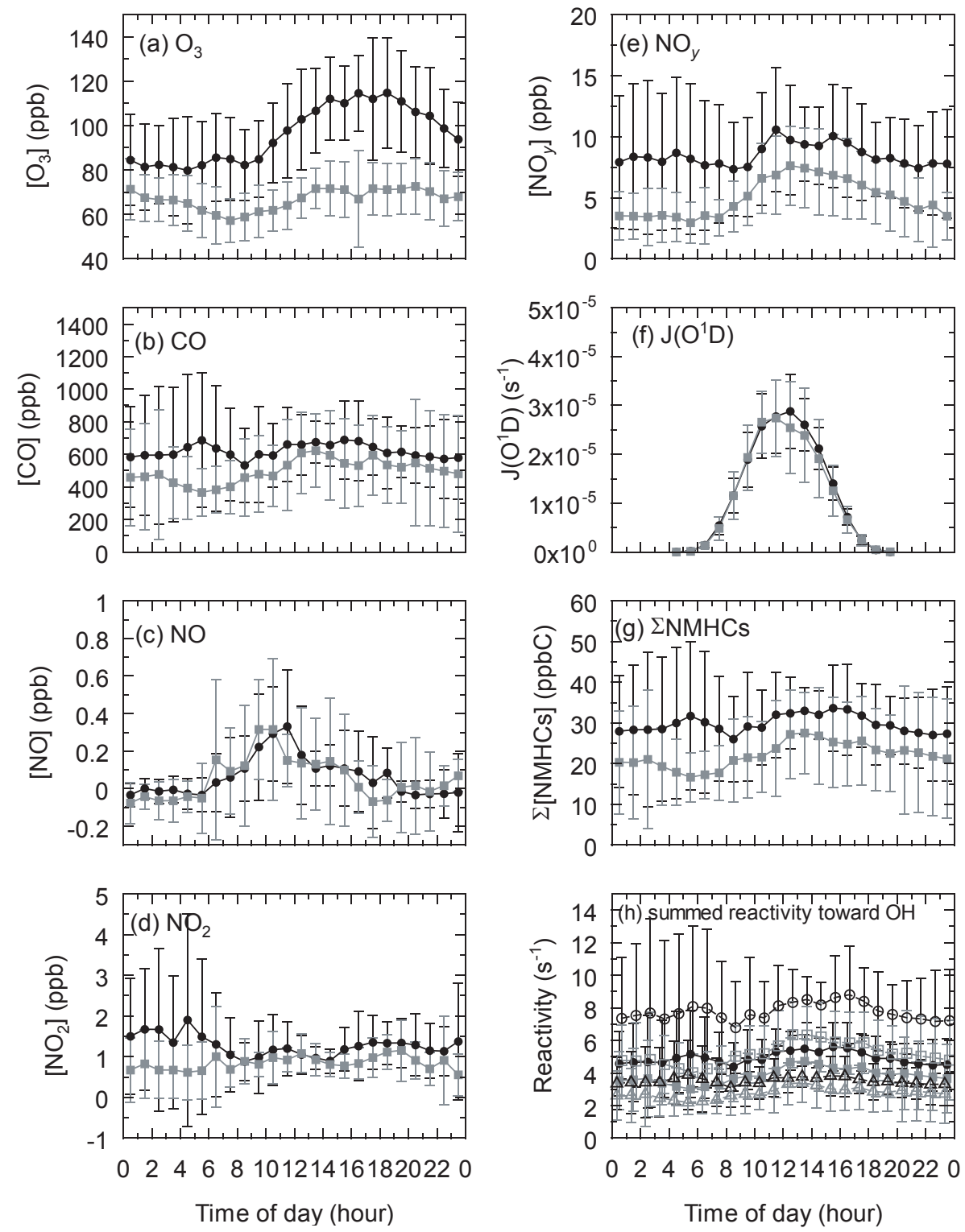

Fig. 1. Averaged diurnal variations in (a) $\mathrm{O}_{3}$, (b) $\mathrm{CO}$, (c) $\mathrm{NO}$, (d) $\mathrm{NO}_{2}$, and (e) $\mathrm{NO}_{\mathrm{y}}$ concentrations, (f) $J\left(\mathrm{O}^{1} D\right.$ ), (g) total $\mathrm{NMHC}$ concentrations (not including oxygenated VOCs), and (h) summed reactivity of $\mathrm{CO}, \mathrm{CH}_{4}, \mathrm{H}_{2}, \mathrm{SO}_{2}$, and $\mathrm{NMHCs}$ toward $\mathrm{OH}$ for high- $\mathrm{O}_{3}$ days (solid circles) and low- $\mathrm{O}_{3}$ days (gray filled squares). In (h), open circles and gray open squares are the reactivity when the contribution from oxygenated VOCs is added for high- and low- $\mathrm{O}_{3}$ days, respectively. Open triangles and gray open triangles are the reactivity of $\mathrm{CO}, \mathrm{CH}_{4}$, $\mathrm{H}_{2}$, and $\mathrm{SO}_{2}$ for high- and low- $\mathrm{O}_{3}$ days, respectively (shown for reference).

\section{Model calculations}

The photochemical box model we used is based on the Regional Atmospheric Chemistry Mechanism (RACM) designed by Stockwell et al. (1997), employing 237 reactions and 77 chemical species. The model has been outlined elsewhere (Kanaya et al., 2007). The observed concentrations of $\mathrm{O}_{3}, \mathrm{CO}, \mathrm{H}_{2} \mathrm{O}, \mathrm{NO}, \mathrm{NO}_{2}$, hydrocarbons, $\mathrm{HCHO}, \mathrm{CH}_{3} \mathrm{CHO}$, $\mathrm{CH}_{3} \mathrm{OH}, \mathrm{MVK}+\mathrm{MACR}$, and MEK, temperature, and $J$ values were averaged or interpolated with a time resolution of
$10 \mathrm{~min}$ and used as constraints of the model. Data gaps were basically filled by time interpolation. In the base run, a NO concentration of $0.05 \mathrm{ppb}$ was assumed when the observation was below the detection limit. This applied to $\sim 30 \%$ of the midday 6-h periods (09:00-15:00 CST) of the studied period (3-30 June). Sensitivity runs assuming 0.02 or $0.1 \mathrm{ppb}$ of NO instead of $0.05 \mathrm{ppb}$ did not change the conclusion of the study significantly (see Sect. 4.2).

Table 1 shows the categorization of the observed hydrocarbons and oxygenated VOCs into lumped species used for the 
RACM. The concentrations of major anthropogenic hydrocarbons ( 25 species, second column in Table 1) measured by GC-FID and GC-MS were taken into account using regression equations for $\mathrm{CO}$, for which continuous observations were available. Two regression equations, one for the first half of the campaign period (3-15 June) and the other for the latter half (16-30 June), were produced and applied for the periods. The $R^{2}$ values for the correlations between $\mathrm{CO}$ and hydrocarbon concentrations ranged between 0.01 and 0.88 . Some hydrocarbons had different slopes for their concentration against $\mathrm{CO}$ concentration in the two periods; it is likely that intense biomass burning of crop residues affected the concentration ratios in the first half period (Suthawaree et al., 2009).

Other minor hydrocarbons ( 21 species, third column in Table 1) detected by GC-FID and GC-MS were taken as having constant concentrations, calculated as mean values over the campaign period. For $\mathrm{HCHO}, \mathrm{CH}_{3} \mathrm{OH}$, acetaldehyde (ALD), acetone, MVK+MACR, and MEK, hourly data from the PTR-MS instrument were used after 15:00 CST on 12 June, when the measurements began. Regression equations with $\mathrm{CO}$ concentrations were used for each of the oxygenated species to estimate their concentrations before 12 June.

For benzene, PTR-MS data were used after the measurements began (15:00 CST on 12 June). The benzene concentrations before this time were estimated from the relationship between $\mathrm{CO}$ and benzene (GC-FID) observed before 15 June. Concentrations of isoprene and monoterpenes were based on hourly data from PTR-MS after 15:00 CST on 12 June. In the case of monoterpenes, averaged fractions of $\alpha$-pinene, $\beta$-pinene, camphene, and limonene over the campaign were used to calculate species-specific concentrations. Averaged diurnal variations in isoprene and monoterpene concentrations from PTR-MS were applied to estimate their concentrations for the period prior to 12 June. For benzene, isoprene, and monoterpenes, the PTR-MS data were scaled to the concentrations determined by GC-FID using the slopes of their regression lines.

The uncertainty in the NMHC concentrations determined in these ways was roughly estimated to be a factor of 2 . The benzene concentrations estimated by the method mentioned above showed similar variation patterns to those directly observed by PTR-MS after 12 June (see Fig. S1 of the supplement material: http://www.atmos-chem-phys. net/9/7711/2009/acp-9-7711-2009-supplement.pdf) and the central $80 \%$ of the ratio between the two concentrations was in a range of $0.80-1.67$. Additionally, we found that $84 \%$ of the concentrations of important NMHCs (having large reactivity toward $\mathrm{OH}$ ) estimated by the method above deviated from the directly measured concentrations by less than a factor of 2. The influence of the uncertainty on the estimation of the ozone production rate will be discussed in Sect. 4.3.

$\mathrm{SO}_{2}$ concentrations were estimated from the equation $\left[\mathrm{SO}_{2}(\mathrm{ppb})\right]=0.018 \times[\mathrm{CO}(\mathrm{ppb})]+4.8$, as observed at Lin'an in March 2001 (Carmichael et al., 2003b). $\mathrm{CH}_{4}$ and $\mathrm{H}_{2}$
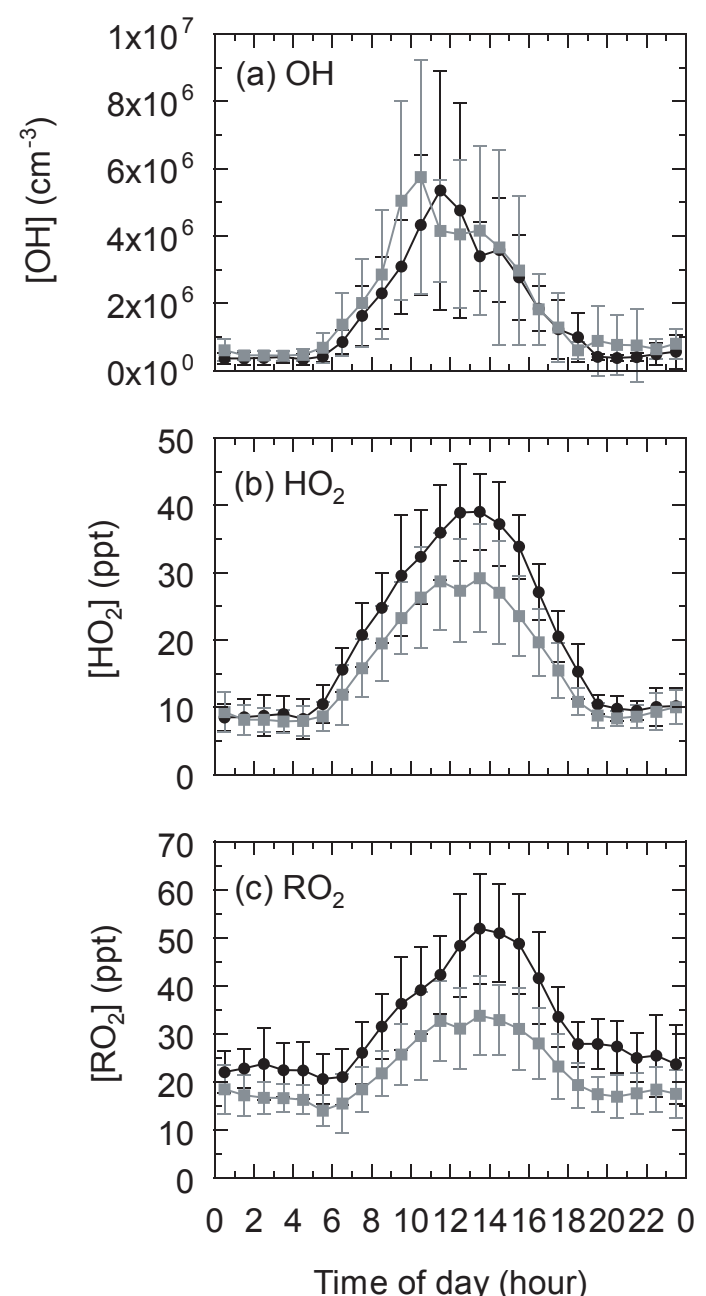

Fig. 2. Average diurnal variations in $\mathrm{OH}, \mathrm{HO}_{2}$, and $\mathrm{RO}_{2}$ concentrations estimated by a photochemical box model for high- $\mathrm{O}_{3}$ days (circles) and low- $\mathrm{O}_{3}$ days (gray squares).

concentrations were assumed to be constant as 1850 and $550 \mathrm{ppbv}$, respectively.

The model calculation was made for each day within the period of 3-30 June (28 days). The time of 00:00 CST was regarded as the initial time on each day, and integration over $24 \mathrm{~h}$ was conducted by 10 -min binning of the data. This integration was conducted ten times in series to stabilize the concentrations of unconstrained species (e.g., unmeasured carbonyl and peroxide species). The results for the last $24 \mathrm{~h}$ were used as output for each day. The $\mathrm{H}_{2} \mathrm{O}_{2}$ concentrations did not stabilize even by the 10th day of calculation, but the effect on the radical concentrations (and thus on the ozone production rate) was small.

Figure 1 shows averaged diurnal variations in concentrations of $\mathrm{O}_{3}, \mathrm{CO}, \mathrm{NO}, \mathrm{NO}_{2}, \mathrm{NO}_{\mathrm{y}}$, and $\Sigma$-nonmethane hydrocarbons (NMHCs) (not including oxygenated VOCs), the summed reactivity of $\mathrm{CO}, \mathrm{CH}_{4}, \mathrm{H}_{2}, \mathrm{SO}_{2}$, hydrocarbons, and 
Table 2. Major production and loss processes of $\mathrm{OH}, \mathrm{HO}_{2}$, and radical $\left(\mathrm{OH}+\mathrm{HO}_{2}+\mathrm{RO}_{2}\right)$ and their fractions as daytime averages $(09: 00-$ 15:00 (ST) $)^{\mathrm{a}}$.

\begin{tabular}{|c|c|c|c|c|c|c|c|c|c|c|c|}
\hline \multicolumn{2}{|c|}{$\begin{array}{c}\text { OH production } \\
4.3 \times 10^{7} \mathrm{~cm}^{-3} \mathrm{~s}^{-1}\end{array}$} & \multicolumn{2}{|c|}{$\begin{array}{c}\text { OH loss } \\
4.3 \times 10^{7} \mathrm{~cm}^{-3} \mathrm{~s}^{-1}\end{array}$} & \multicolumn{2}{|c|}{$\begin{array}{c}\mathrm{HO}_{2} \text { production } \\
3.8 \times 10^{7} \mathrm{~cm}^{-3} \mathrm{~s}^{-1}\end{array}$} & \multicolumn{2}{|c|}{$\begin{array}{c}\mathrm{HO}_{2} \text { loss } \\
3.9 \times 10^{7} \mathrm{~cm}^{-3} \mathrm{~s}^{-1}\end{array}$} & \multicolumn{2}{|c|}{$\begin{array}{l}\text { Radical production } \\
2.1 \times 10^{7} \mathrm{~cm}^{-3} \mathrm{~s}^{-1}\end{array}$} & \multicolumn{2}{|c|}{$\begin{array}{c}\text { Radical loss } \\
2.1 \times 10^{7} \mathrm{~cm}^{-3} \mathrm{~s}^{-1}\end{array}$} \\
\hline $\mathrm{HO}_{2}+\mathrm{NO}$ & 0.59 & $\mathrm{OH}+\mathrm{CO}$ & 0.27 & $\mathrm{OH}+\mathrm{CO}$ & 0.30 & $\mathrm{HO}_{2}+\mathrm{NO}$ & 0.65 & $\mathrm{O}^{1} \mathrm{D}+\mathrm{H}_{2} \mathrm{O}$ & 0.43 & $\mathrm{HC} 3 \mathrm{P}+\mathrm{HO}_{2}$ & 0.14 \\
\hline $\mathrm{O}^{1} \mathrm{D}+\mathrm{H}_{2} \mathrm{O}$ & 0.22 & $\mathrm{OH}+\mathrm{ALD}$ & 0.12 & $\mathrm{CH}_{3} \mathrm{O}_{2}+\mathrm{NO}$ & 0.19 & $\mathrm{HO}_{2}+\mathrm{HO}_{2}$ & 0.07 & $\mathrm{HCHO}+h v$ & 0.09 & $\mathrm{HO}_{2}+\mathrm{HO}_{2}$ & 0.13 \\
\hline $\mathrm{O}_{3}+\mathrm{HO}_{2}$ & 0.05 & $\mathrm{OH}+\mathrm{OP} 2$ & 0.08 & $\mathrm{HCHO}+h v$ & 0.05 & $\mathrm{HO}_{2}+\mathrm{HO}_{2}+\mathrm{H}_{2} \mathrm{O}$ & 0.07 & $\mathrm{H}_{2} \mathrm{O}_{2}+h v$ & 0.09 & $\mathrm{HO}_{2}+\mathrm{HO}_{2}+\mathrm{H}_{2} \mathrm{O}$ & 0.12 \\
\hline $\mathrm{H}_{2} \mathrm{O}_{2}+h v$ & 0.04 & $\mathrm{OH}+\mathrm{HC} 3$ & 0.06 & $\mathrm{HC} 3 \mathrm{P}+\mathrm{NO}$ & 0.05 & $\mathrm{O}_{3}+\mathrm{HO}_{2}$ & 0.06 & MGLY+hv & 0.08 & $\mathrm{CH}_{3} \mathrm{O}_{2}+\mathrm{HO}_{2}$ & 0.10 \\
\hline $\mathrm{OP} 2+\mathrm{OH}$ & 0.04 & $\mathrm{OH}+\mathrm{ISO}$ & 0.05 & $\mathrm{HCHO}+\mathrm{OH}$ & 0.05 & $\mathrm{HC} 3 \mathrm{P}+\mathrm{HO}_{2}$ & 0.04 & $\mathrm{OP} 2+h v$ & 0.06 & $\mathrm{ISOP}+\mathrm{HO}_{2}$ & 0.06 \\
\hline $\mathrm{OP} 2+h v$ & 0.01 & $\mathrm{OH}+\mathrm{MACR}$ & 0.04 & $\mathrm{ISOP}+\mathrm{NO}$ & 0.03 & $\mathrm{CH}_{3} \mathrm{O}_{2}+\mathrm{HO}_{2}$ & 0.03 & $\mathrm{MACR}+\mathrm{OH}$ & 0.04 & $\mathrm{XO} 2+\mathrm{HO}_{2}$ & 0.06 \\
\hline $\mathrm{LIM}+\mathrm{O}_{3}$ & 0.01 & $\mathrm{OH}+\mathrm{HCHO}$ & 0.04 & $\mathrm{OH}+\mathrm{SO}_{2}$ & 0.03 & $\mathrm{XO} 2+\mathrm{HO}_{2}$ & 0.02 & $\mathrm{LIM}+\mathrm{O}_{3}$ & 0.04 & $\mathrm{XO} 2+\mathrm{NO}$ & 0.05 \\
\hline $\mathrm{OP} 1+\mathrm{OH}$ & 0.01 & $\mathrm{OH}+\mathrm{H}_{2} \mathrm{O}_{2}$ & 0.03 & $\mathrm{H}_{2} \mathrm{O}_{2}+\mathrm{OH}$ & 0.03 & $\mathrm{ISOP}+\mathrm{HO}_{2}$ & 0.01 & $\mathrm{ALD}+h v$ & 0.03 & $\mathrm{OH}+\mathrm{NO}_{2}$ & 0.05 \\
\hline $\mathrm{API}+\mathrm{O}_{3}$ & 0.01 & $\mathrm{OH}+\mathrm{LIM}$ & 0.03 & $\mathrm{HC} 3+\mathrm{OH}$ & 0.03 & $\mathrm{LIMP}+\mathrm{HO}_{2}$ & 0.01 & $\mathrm{API}+\mathrm{O}_{3}$ & 0.02 & $\mathrm{LIMP}+\mathrm{HO}_{2}$ & 0.04 \\
\hline $\mathrm{OP} 1+h v$ & 0.00 & $\mathrm{OH}+\mathrm{SO}_{2}$ & 0.03 & others & 0.24 & others & 0.05 & $\mathrm{MACR}+h v$ & 0.02 & $\mathrm{ACO} 3+\mathrm{HO}_{2}$ & 0.04 \\
\hline \multirow[t]{2}{*}{ others } & 0.01 & $\mathrm{OH}+\mathrm{NO}_{2}$ & 0.02 & & & & & others & 0.11 & $\mathrm{OH}+\mathrm{HO}_{2}$ & 0.03 \\
\hline & & others & 0.23 & & & & & & & others & 0.20 \\
\hline
\end{tabular}

${ }^{\text {a }}$ Interconversion between $\mathrm{HO}_{2}$ and $\mathrm{HO}_{2} \mathrm{NO}_{2}$ and between $\mathrm{RO}_{2}$ and PANs is omitted.

See Table 1 for LIM, API, HC3, ALD, ISO, MACR. HC3P, ISOP, and LIMP are peroxy radicals formed from HC3, ISO, and LIM, respectively. $\mathrm{XO} 2$ and $\mathrm{ACO} 3$ are peroxy radicals that account for additional $\mathrm{NO}$ to $\mathrm{NO}_{2}$ conversion and saturated acyl peroxy radicals (acetyl peroxy and higher). OP1, OP2, and MGLY are $\mathrm{CH}_{3} \mathrm{OOH}$, organic peroxide higher than $\mathrm{CH}_{3} \mathrm{OOH}$, and methylglyoxal and other $\alpha$-carbonyl aldehydes.

oxygenated VOCs toward $\mathrm{OH}$, and $J\left(\mathrm{O}^{1} D\right)$ values. They are separately shown for days when hourly $\left[\mathrm{O}_{3}\right]$ exceeded $100 \mathrm{ppbv}$ at least once (high- $\mathrm{O}_{3}$ days: $2-7,11-13,15-16$, $18-20$, and 27 June) and for the other days with lower ozone concentrations (low- $\mathrm{O}_{3}$ days: $8-10,14,17,21-26,28-30$ June). The concentrations of $\mathrm{CO}, \mathrm{NMHCs}$, and $\mathrm{NO}_{y}$ were higher on high- $\mathrm{O}_{3}$ days, implying a larger influence of primary emissions on these days. The concentrations of the precursors had diurnal variations with the daytime maximum especially for the low- $\mathrm{O}_{3}$ days. This analysis suggests that the mountain top observations were affected by the development of the polluted layer in the daytime. $\mathrm{O}_{3}$ concentrations had daytime buildup of 34 and 15 ppbv for high- $\mathrm{O}_{3}$ and low$\mathrm{O}_{3}$ days, respectively. Differences in the $\mathrm{NO}$ and $J\left(\mathrm{O}^{1} D\right)$ levels were small for the two periods, while the $\mathrm{NO}_{2}$ concentrations were slightly higher for the high- $\mathrm{O}_{3}$ days. In Fig. 1h, the magnitudes of contributions of NMHCs and oxygenated VOCs to the reactivity of $\mathrm{OH}$ can be recognized. See Li et al. (2008a) for the day-to-day variations in the concentrations of these key precursors.

\section{Results and discussions}

\subsection{Estimated radical concentrations}

Figure $2 \mathrm{a}-\mathrm{c}$ shows diurnal variations in the calculated concentrations of $\mathrm{OH}, \mathrm{HO}_{2}$, and $\mathrm{RO}_{2}$ radicals. They were calculated for individual days and then averaged for the high- $\mathrm{O}_{3}$ and low- $\mathrm{O}_{3}$ days, respectively. The $\mathrm{OH}$ concentrations for low- $\mathrm{O}_{3}$ days were higher than those for high-
$\mathrm{O}_{3}$ days until 11:00 CST, because higher NO concentrations for low- $\mathrm{O}_{3}$ days facilitated conversion from $\mathrm{HO}_{2}$ to $\mathrm{OH}$. In the afternoon, the $\mathrm{OH}$ concentrations were quite similar for the two cases. The midday peak concentrations were 5.4 and $5.7 \times 10^{6} \mathrm{~cm}^{-3}$ for high- $\mathrm{O}_{3}$ and low- $\mathrm{O}_{3}$ days, respectively. The 24-h average concentrations were 1.7 and $1.9 \times 10^{6} \mathrm{~cm}^{-3}$. The daytime $\mathrm{HO}_{2}$ and $\mathrm{RO}_{2}$ concentrations were always higher on the high- $\mathrm{O}_{3}$ days; daytime peaks were 39 and 52 pptv in comparison with 29 and 34 pptv on the low$\mathrm{O}_{3}$ days.

Table 2 lists major production and loss processes of $\mathrm{OH}$, $\mathrm{HO}_{2}$ and radicals (the group of $\mathrm{OH}, \mathrm{HO}_{2}$, and $\mathrm{RO}_{2}$ radicals) and their fractions to the total rates as daytime averages (09:00-15:00 CST). For OH production, the $\mathrm{HO}_{2}+\mathrm{NO}$ reaction was more important than ozone photolysis $\left(\mathrm{O}^{1} D+\mathrm{H}_{2} \mathrm{O}\right)$. $\mathrm{OH}$ loss was dominated by its reactions with $\mathrm{CO}, \mathrm{ALD}$, and OP2 (organic peroxide higher than $\mathrm{CH}_{3} \mathrm{OOH}$ ). $\mathrm{HO}_{2}$ production was dominated by the $\mathrm{OH}+\mathrm{CO}$ and $\mathrm{CH}_{3} \mathrm{O}_{2}+\mathrm{NO}$ reactions. $\mathrm{HO}_{2}$ loss occurred mainly through its reactions with $\mathrm{NO}$ and $\mathrm{HO}_{2}$ itself. The initial production of the radicals occurred by the photolysis of ozone, $\mathrm{HCHO}$, and $\mathrm{H}_{2} \mathrm{O}_{2}$. The ultimate loss of the radicals was normally governed by the self and cross reactions of $\mathrm{HO}_{2}$ and $\mathrm{RO}_{2}$. It should be noted that conversion between the radicals and $\mathrm{HNO}_{4}$, peroxyacetyl nitrate (PAN) and higher saturated PANs, and TPAN (unsaturated PANs) was not included in the production or loss of the radical to calculate values in Table 2 .

The production and loss rates of the radicals were in balance. The initial radical production rate was $2.1 \times 10^{7} \mathrm{~cm}^{-3} \mathrm{~s}^{-1}$ as a daytime average, similar to an average $\left(2.2 \times 10^{7} \mathrm{~cm}^{-3} \mathrm{~s}^{-1}\right)$ for summer in the urban center of 
Tokyo (as an average in the period 09:00-15:00 local time) (Kanaya et al., 2007).

\subsection{Photochemical production rate of ozone and its breakdown}

It is known that photochemistry results in both the formation and destruction of ozone in the troposphere and thus the difference between the rates of gross formation $\left(F\left(\mathrm{O}_{3}\right)\right)$ and loss $\left(D\left(\mathrm{O}_{3}\right)\right), F\left(\mathrm{O}_{3}\right)-D\left(\mathrm{O}_{3}\right)$ (hereafter simply termed $\left.F-D\left(\mathrm{O}_{3}\right)\right)$, is the important quantity describing the net photochemical production rate. The terms are given by

$$
F\left(\mathrm{O}_{3}\right)=k_{1}\left[\mathrm{HO}_{2}\right][\mathrm{NO}]+\Sigma k_{2 i}\left[\mathrm{RO}_{2}\right]_{i}[\mathrm{NO}] \phi_{i},
$$

$$
\begin{aligned}
D\left(\mathrm{O}_{3}\right)= & k_{3}\left[\mathrm{O}^{1}(\mathrm{D})\right]\left[\mathrm{H}_{2} \mathrm{O}\right]+k_{4}[\mathrm{OH}]\left[\mathrm{O}_{3}\right]+k_{5}\left[\mathrm{HO}_{2}\right]\left[\mathrm{O}_{3}\right] \\
& +\Sigma k_{6 j}\left[\mathrm{O}_{3}\right][\text { olefin }]_{j} \\
F-D\left(\mathrm{O}_{3}\right)= & F\left(\mathrm{O}_{3}\right)-D\left(\mathrm{O}_{3}\right)
\end{aligned}
$$

where $k_{1}-k_{6}$ are the rate coefficients of the $\mathrm{HO}_{2}+\mathrm{NO}$, $\mathrm{RO}_{2}+\mathrm{NO}, \mathrm{O}\left({ }^{1} D\right)+\mathrm{H}_{2} \mathrm{O}, \mathrm{OH}+\mathrm{O}_{3}, \mathrm{HO}_{2}+\mathrm{O}_{3}$ and $\mathrm{O}_{3}+$ olefin reactions, respectively, and $\phi$ is the yield of $\mathrm{NO}_{2}$ from the $\mathrm{RO}_{2}+\mathrm{NO}$ reaction. $F, D$, and $F-D$ are calculated on the basis of the calculated radical concentrations (Sect. 4.1) and then they are averaged to obtain composite diurnal variations of the rates for the high- and low- $\mathrm{O}_{3}$ days (Fig. 3a-c). $F\left(\mathrm{O}_{3}\right)$ was higher for the high- $\mathrm{O}_{3}$ days during the 10:00-18:00 CST period. This was because the peroxy radical concentrations were higher on the high- $\mathrm{O}_{3}$ days as seen in Fig. 2b. $F\left(\mathrm{O}_{3}\right)$ for the high- $\mathrm{O}_{3}$ days was slightly lower at 09:00 CST because the NO concentrations were lower than they were for the low- $\mathrm{O}_{3}$ days (Fig. 1c), compensating the higher peroxy radical concentrations when they are multiplied together. The gross production of ozone per day was estimated to be $85 \pm 43$ and $60 \pm 32$ ppb for high- and low- $\mathrm{O}_{3}$ days, respectively, by integrating $F\left(\mathrm{O}_{3}\right)$ from morning (05:00 CST) to evening (20:00 CST). $D\left(\mathrm{O}_{3}\right)$ was larger for high- $\mathrm{O}_{3}$ days because it was proportional to the ozone concentration in the atmosphere. The integrated gross losses per day were $18 \pm 5$ and $11 \pm 3$ ppb for the high- and low- $\mathrm{O}_{3}$ days, respectively. Because of the larger compensation by $D\left(\mathrm{O}_{3}\right)$ during the high- $\mathrm{O}_{3}$ days, the difference in $F-D\left(\mathrm{O}_{3}\right)$ for the two periods was small. The integrated net production was estimated to be $67 \pm 41$ and $49 \pm 32 \mathrm{ppb}$, respectively. As an average over the campaign period, $58 \pm 37 \mathrm{ppb}$ of daily ozone production was expected. This value is larger than $32 \mathrm{ppb} \mathrm{d}^{-1}$, the photochemical production rate of ozone estimated in a model for the grid surrounding the Mount Tai station (surface area of $400 \times 400 \mathrm{~km}$ with $0-2.5 \mathrm{~km}$ altitude range) in June (Li et al., 2007). This may be because the nighttime loss chemistry was taken into account and precursor concentrations were not constrained in Li et al.'s model calculation.

Our value is larger than the production rate $\left(38 \mathrm{ppb} \mathrm{day}^{-1}\right)$ estimated from the slope of a regression line for the ozone
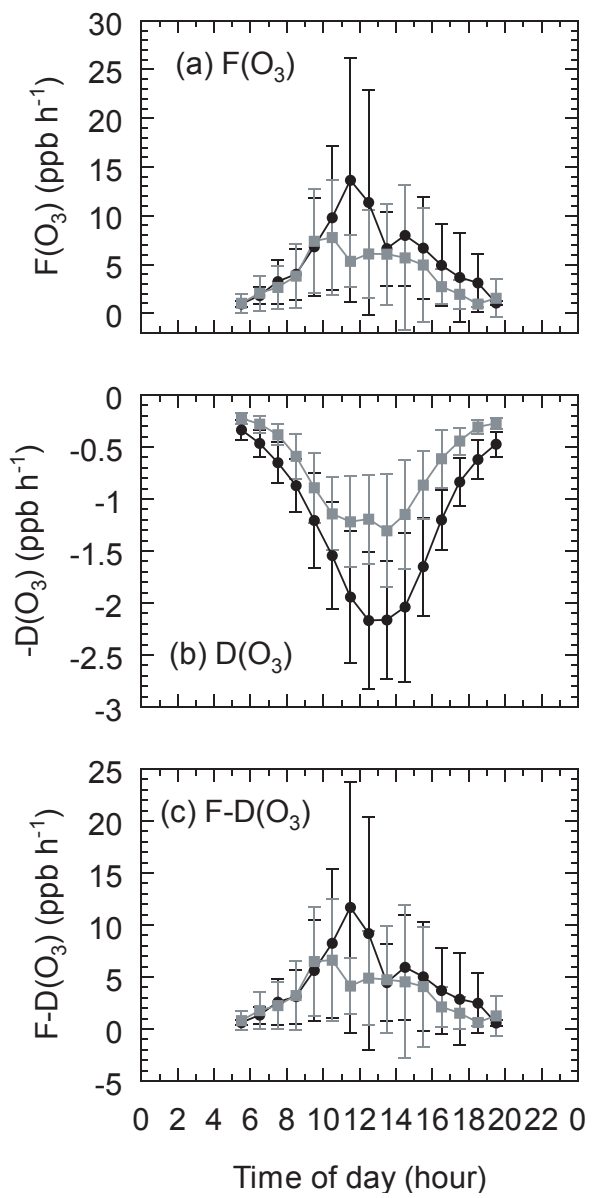

Fig. 3. Average diurnal variations in $F\left(\mathrm{O}_{3}\right), D\left(\mathrm{O}_{3}\right)$, and $F-D\left(\mathrm{O}_{3}\right)$ for high- $\mathrm{O}_{3}$ days (circles) and low- $\mathrm{O}_{3}$ days (gray squares).

concentration observed at the same location in 2004 and the residence time of the air mass over the Central East China region based on the backward trajectory analysis (Pochanart et al., 2009). The difference would be attributed to dilution and deposition, effective only for the rate estimated using the residence time.

Our results are relatively insensitive to the assumption that NO concentrations were set to $0.05 \mathrm{ppb}$ when measurements were below the detection limit. The average daily net productions were estimated to be 53 and $66 \mathrm{ppb}$ when assuming 0.02 and $0.1 \mathrm{ppb}$ of NO instead of $0.05 \mathrm{ppb}$.

This analysis implies that 67 and $49 \mathrm{ppb}$ of ozone were produced each day by in situ photochemistry on high- and low- $\mathrm{O}_{3}$ days, respectively. These amounts were larger than the daytime increases in the ozone concentration observed at the mountain top ( 34 and $15 \mathrm{ppbv}$ ), suggesting that the in situ photochemistry is active enough to explain the ozone buildup in both cases, while the transportation of polluted air from lower altitude, as recognized by the daytime buildup of primary pollutants, may also be important. It should also be noted that the ratio between the daily production amounts on 


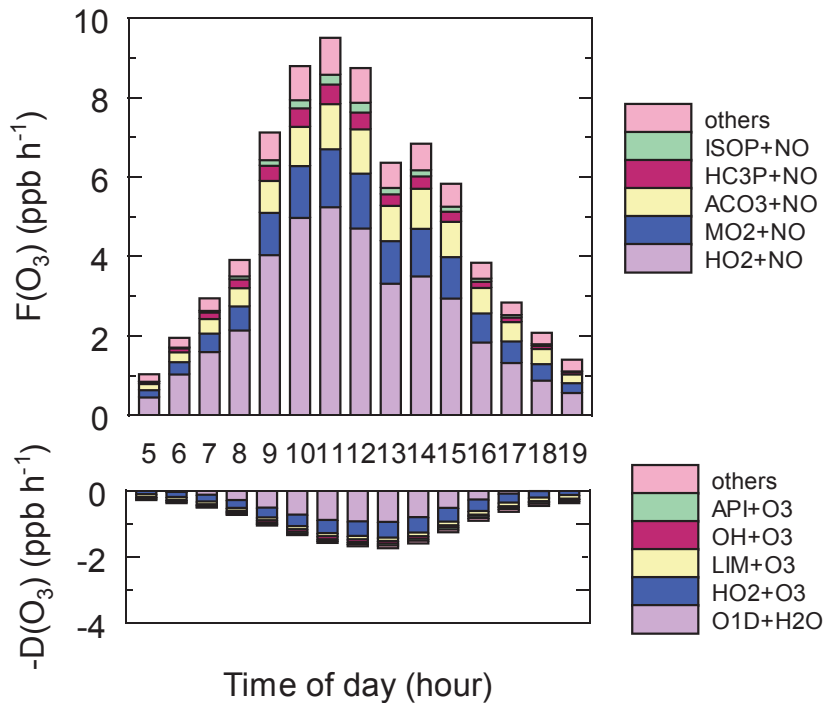

Fig. 4. Breakdown of $F\left(\mathrm{O}_{3}\right)$ and $D\left(\mathrm{O}_{3}\right)$ terms as averages over the campaign.

the high- and low- $\mathrm{O}_{3}$ days (i.e., $67 / 49=1.4$ ) was not as large as the ratio of the daytime increase in the observed ozone concentrations for the two periods (i.e., $34 / 15=2.3$ ). This indicates that the observed buildup of ozone concentrations in the daytime was not merely affected by local chemistry. Li et al. $(2008 \mathrm{a}, \mathrm{b})$ revealed the importance of both in situ chemistry and region-wide chemistry coupled with transport for ozone in a three-dimensional regional scale model.

The daytime 6-h averages of $F-D\left(\mathrm{O}_{3}\right)$ and $F\left(\mathrm{O}_{3}\right)$ were 6.4 and $7.9 \mathrm{ppbh}^{-1}$ for this campaign. The former value is in rough agreement with the in situ production rate $\left(\sim 5 \mathrm{ppb} \mathrm{h}^{-1}\right)$ estimated in a three-dimensional regional scale modeling study ( $\mathrm{Li}$ et al., 2008b). The latter value falls into a range of the rates estimated for the boundary layer over major cities in the United Sates; our value is slightly lower than those over Philadelphia (11.3 $\mathrm{ppbh}^{-1}$ for July and August 1999) and Houston (11.3 $\mathrm{ppb} \mathrm{h}^{-1}$ for August and September 2000), but higher than those over Nashville $\left(6.2 \mathrm{ppb} \mathrm{h}^{-1}\right.$ for June and July 1995), New York City $\left(4.3 \mathrm{ppbh}^{-1}\right.$ for July 1996), and Phoenix (3.5 $\mathrm{pph} \mathrm{h}^{-1}$ for May and June 1998) (Kleinmann et al., 2002). The production rates for Mount Tai are significantly higher than the $F-D\left(\mathrm{O}_{3}\right)$ values at other mountain stations: from -0.05 to $+0.4 \mathrm{ppb} \mathrm{h}^{-1}$ at Jungfraujoch (3590 $\mathrm{m}$ a.s.l.) for midday in winter, spring, and summer (Parker et al., 2009; Zanis et al., 2003), 2-3 $\mathrm{ppb} \mathrm{d}^{-1}$ for Mt. Cimone (2165 m a.s.l.) in June (Fischer et al., 2003), and from -0.8 to $-0.4 \mathrm{ppb} \mathrm{d}^{-1}$ for Mauna Loa (3.4 km a.s.1.) for four seasons (Cantrell et al., 1996). Forward trajectory analysis suggests that the air mass leaving the top of Mount Tai stays $22 \mathrm{~h}$ (as median) longer within the boundary layer over CEC $\left(31-40^{\circ} \mathrm{N}, 114-121^{\circ} \mathrm{E}, 0-2000 \mathrm{~m}\right.$ altitude), producing a large amount of ozone in this region in the daytime.

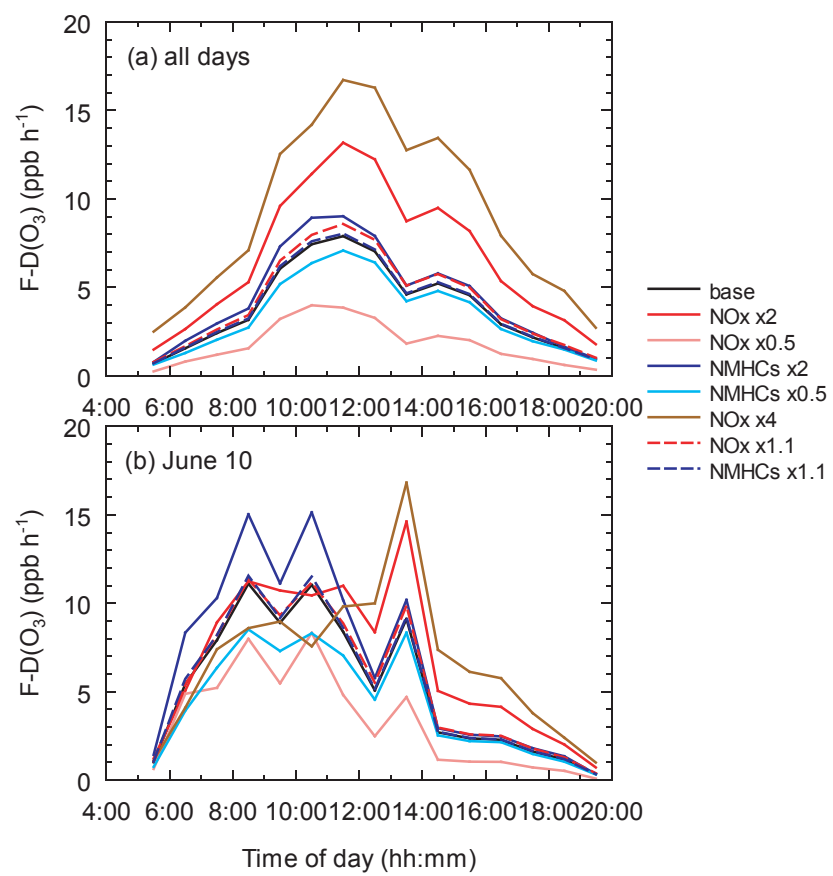

Fig. 5. Average diurnal variations in $F-D\left(\mathrm{O}_{3}\right)$ for the base run (black) and sensitivity runs (colored).

Figure 4 shows the contribution from each chemical process to the $F\left(\mathrm{O}_{3}\right)$ and $D\left(\mathrm{O}_{3}\right)$ terms as an average over the campaign period. The reaction of $\mathrm{HO}_{2}$ with $\mathrm{NO}$ dominated the $F\left(\mathrm{O}_{3}\right)$ term, followed by the reactions of $\mathrm{MO} 2$ $\left(\mathrm{CH}_{3} \mathrm{O}_{2}\right)$, ACO3 $\left(\mathrm{CH}_{3} \mathrm{COO}_{2}\right.$ and higher acyl peroxy radicals), and ISOP (isoprene peroxy radicals) with NO. The dominant term in $D\left(\mathrm{O}_{3}\right)$ was the $\mathrm{O}\left({ }^{1} D\right)+\mathrm{H}_{2} \mathrm{O}$ reaction.

\subsection{Estimation of regimes}

We performed sensitivity model runs, where $\mathrm{NO}_{\mathrm{x}}$ concentrations were artificially multiplied by factors of $0.5,1.1,2$, or 4 while NMHCs concentrations were kept unchanged from the base run, and runs where NMHCs concentrations were conversely multiplied by factors of $0.5,1.1$, or 2 while $\mathrm{NO}_{\mathrm{x}}$ concentrations were unchanged. Together with the changes in NMHCs concentrations, $\mathrm{CO}$ and $\mathrm{CH}_{4}$ concentrations were also scaled by the same factors but with consideration of their background concentrations. The background concentration of ethane was also taken into account. The results of the averaged diurnal variations in $F-D\left(\mathrm{O}_{3}\right)$ from the sensitivity runs are summarized in Fig. 5a. The analysis suggested that $F-D\left(\mathrm{O}_{3}\right)$ was much more sensitive to $\mathrm{NO}_{\mathrm{x}}$ concentrations than to NMHCs, clearly indicating that ozone production was $\mathrm{NO}_{\mathrm{x}}$-limited. The analysis also implied that the ozone production should have been more efficient when the air mass was fresh and the $\mathrm{NO}_{\mathrm{x}} / \mathrm{NO}_{\mathrm{y}}$ ratios (and thus the $\mathrm{NO}_{\mathrm{x}}$ concentration for a given $\mathrm{NO}_{\mathrm{y}}$ concentration for that air mass) was higher than that observed on the mountain $(\sim 0.18$ as 


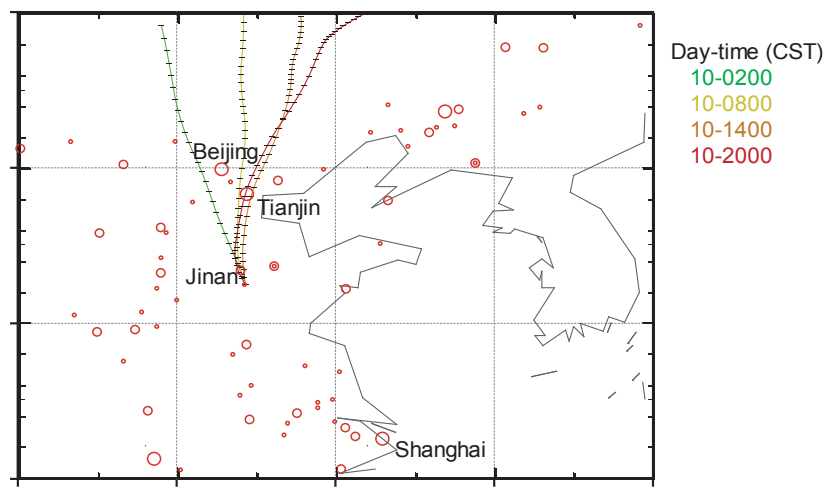

Fig. 6. Backward trajectories on 10 June 2006 with different starting time (separated by $6 \mathrm{~h}$ ). Tick marks on the trajectories indicate the hourly position of the air mass. Major cities in China are shown by red open circles.

an average over the campaign period). Additionally, the importance of the $\mathrm{NO}_{\mathrm{x}}$-limited regime indicates that the ozone pollution will be severer in the future owing to stronger $\mathrm{NO}_{\mathrm{x}}$ emission anticipated in CEC (Yamaji et al., 2008; Ohara et al., 2007). Our result suggesting a $\mathrm{NO}_{\mathrm{x}}$-limited condition in June for this region is consistent with that of Martin et al. (2004) based on satellite observations. Because of the dominance of the $\mathrm{NO}_{\mathrm{x}}$-limited condition, the uncertainty in the NMHC concentrations of a factor of 2 propagated to the uncertainty in the daily production of ozone (on the basis of $\left.F-D\left(\mathrm{O}_{3}\right)\right)$ of a factor of only 1.15 (Fig. 5a).

We found that the morning of 10 June was an exceptional period, when $F-D\left(\mathrm{O}_{3}\right)$ was sensitive to NMHC concentrations rather than to the $\mathrm{NO}_{x}$ concentration (Fig. 5b). We calculated 10-day kinematic backward trajectories using the CGER-METEX program (http://db.cger.nies.go.jp/ metex/) for 6-h intervals during the campaign period, using the National Centers for Environmental Prediction meteorological reanalysis field as input. The starting altitude of the trajectories was $1500 \mathrm{~m}$. The analysis showed that the air mass on 10 June quickly intruded from the north to the Mt. Tai region and passed over Jinan (the capital of Shandong Province, with a population of 3 million and located $\sim 60 \mathrm{~km}$ north of the observatory) only 1 or $2 \mathrm{~h}$ before the arrival of the air mass at the observatory (Fig. 6). Consistently, the $\mathrm{NO}_{\mathrm{x}} / \mathrm{NO}_{\mathrm{y}}$ ratio during the period (Fig. 7a) was exceptionally high, suggesting that fresh air pollution affected the observed air mass. The analysis suggests the possibility that the ozone production regime in the city tended to be VOClimited and changed to being $\mathrm{NO}_{\mathrm{x}}$-limited during the travel of the air mass, with conversion of $\mathrm{NO}_{\mathrm{x}}$ to $\mathrm{NO}_{\mathrm{Z}}\left(\mathrm{HNO}_{3}\right.$ and PANs) occurring more rapidly than the oxidation of NMHCs did. There were other periods on 8, 9, 11, 15, 23, and 24 June when ozone was produced under VOC-limited conditions, as marked by open squares in Fig. 7a. Here our definition of VOC-limited is that multiplying a factor of 1.1 to NMHC
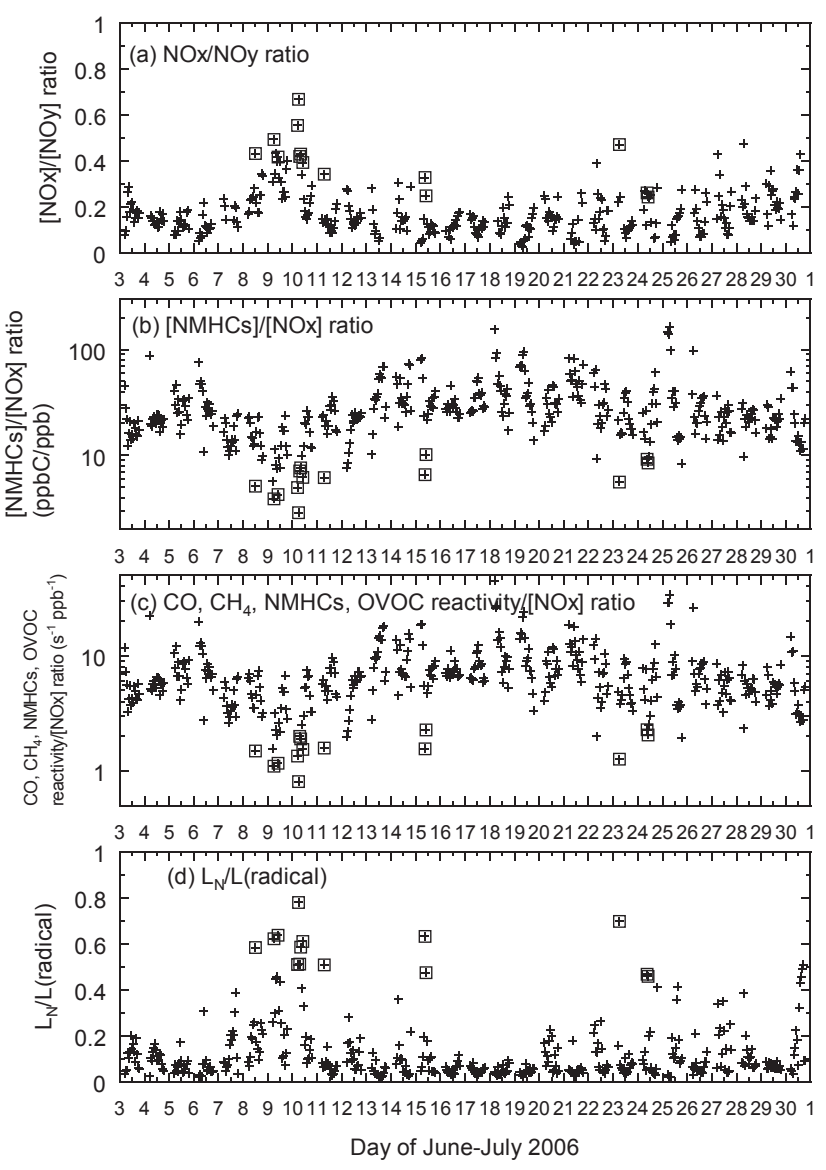

Fig. 7. Temporal variations in (a) the $\mathrm{NO}_{\mathrm{x}} / \mathrm{NO}_{\mathrm{y}}$ ratio, (b) the $\mathrm{NMHCs} / \mathrm{NO}_{\mathrm{x}}$ ratio, (c) the reactivity/ $\mathrm{NO}_{\mathrm{x}}$ ratio, and (d) the $L_{N} / L$ (radical) ratio during the campaign. The data points associated with VOC-limited conditions are marked with open squares.

concentrations results in higher $F-D\left(\mathrm{O}_{3}\right)$ values than multiplying the same factor to the $\mathrm{NO}_{\mathrm{x}}$ concentrations does. VOClimited conditions mostly occurred during the morning and were interestingly associated with high $\mathrm{NO}_{\mathrm{x}} / \mathrm{NO}_{\mathrm{y}}$ ratios in all cases, similar to the case for the morning of 10 June. It should be noted that the observed $\mathrm{NO}_{\mathrm{y}}$ concentrations used in this analysis were neither the input nor the output of the model calculations.

The VOC-limited periods were associated with lower $\mathrm{NMHCs} / \mathrm{NO}_{\mathrm{x}}$ ratios (Fig. 7b), as past studies have found. From Fig. 7b, it is deduced that transition from the $\mathrm{NO}_{\mathrm{x}}{ }^{-}$ limited regime to the VOC-limited regime occurred at an $\mathrm{NMHC} / \mathrm{NO}_{\mathrm{x}}$ ratio of $\sim 10 \mathrm{ppbC} / \mathrm{ppb}$. Although not shown, if $\mathrm{NMHC}+$ oxygenated VOC concentrations are used for the vertical axis instead of the NMHC concentration, the $(\mathrm{NMHC}+$ oxygenated $\mathrm{VOC}) / \mathrm{NO}_{\mathrm{x}}$ ratio of $\sim 25 \mathrm{ppbC} / \mathrm{ppb}$ corresponded to the transition. The critical $\mathrm{NMHCs} / \mathrm{NO}_{\mathrm{x}}$ ratio falls into the range suggested by Sillman (1999) (10$20 \mathrm{ppbC} / \mathrm{ppb}$ ) for summer at mid-latitude and is also roughly in agreement with the value for summertime Tokyo at ground 
level (around $20 \mathrm{ppbC} / \mathrm{ppb}$ ) determined using the same tropospheric chemistry mechanism (Kanaya et al., 2008). We also conducted similar analysis using the sum reactivity of $\mathrm{CO}, \mathrm{CH}_{4}, \mathrm{H}_{2}, \mathrm{SO}_{2}, \mathrm{NMHCs}$, and oxygenated VOCs toward $\mathrm{OH}$ (which propagate radical chain reactions) instead of using the concentrations. The results (Fig. 7c) suggest that the transition between the two regimes occurred around $2 \mathrm{~s}^{-1} \mathrm{ppb}^{-1}$. This is slightly higher than $1 \mathrm{~s}^{-1} \mathrm{ppb}^{-1}$ suggested by Kleinman et al. (2005) for the boundary layer over cities in the United States. The fraction of the radi$\mathrm{cal}+\mathrm{NO}_{\mathrm{x}}$ reaction rates $\left(L_{N}\right)$ to the total radical termination rate $(L$ (radical)) was greater than 0.5 for the VOC-limited data points (Fig. 7d). In this case, the $\mathrm{OH}+\mathrm{NO}_{2}+\mathrm{M}$ and $\mathrm{XO} 2$ (peroxy radicals that account for additional $\mathrm{NO}$ to $\mathrm{NO}_{2}$ conversion)+NO reactions contributed largely to $L_{N}$. This is qualitatively consistent with the results of Kleinman et al. (2005), in which the contribution from the $\mathrm{NO}_{\mathrm{x}}$-related processes to the radical termination increased under VOClimited conditions.

Although the ozone production rates and regimes determined in this study are based on the point measurement at the top of Mt. Tai, they would be representative for a wider background region without strong influence of fresh pollution, assuming the concentrations of ozone precursors are relatively uniform and our data are representative. Considering that more than half of the 10-day-long backward trajectories arriving at the top of Mt. Tai for June 2006 did not travel over any Chinese large cities (91 cities with populations more than 500000), the regional production of ozone under the $\mathrm{NO}_{\mathrm{x}}$-limited condition and its accumulation over multiple days can be one of the major causes for the high $\mathrm{O}_{3}$ levels at a regional scale. See Li et al. (2008a) for detailed analysis based on a 3-dimensional model that combines the regional-wide ozone production and vertical and horizontal transport for this campaign period.

\subsection{Other sensitivity studies}

We made additional sensitivity runs where (1) the $\mathrm{CO}$ concentrations were constrained to $90 \mathrm{ppb}$ for all time, (2) the ALD concentrations were scaled down by a factor of 3 , (3) concentrations of biogenic hydrocarbons (isoprene and monoterpenes) were set to zero, and (4) the heterogeneous loss of $\mathrm{HO}_{2}$ radicals on aerosol surfaces was taken into account.

\subsubsection{CO}

One of the significant features of atmospheric composition over China is that the $\mathrm{CO}$ concentration is very high (the monthly mean was $560 \mathrm{ppb}$ on average during the campaign). Therefore, we examined the role of $\mathrm{CO}$ in the photochemistry. Constraining the $\mathrm{CO}$ concentration to $90 \mathrm{ppb}$ (minimum concentration observed during the campaign) for all time resulted in a daily production of ozone of $58 \mathrm{ppb}$, which was the same as the value for the base run $(58 \mathrm{ppb})$. This run suggests that the other hydrocarbons were present at sufficiently high concentrations to cycle $\mathrm{OH}$ to $\mathrm{RO}_{2}\left(\mathrm{HO}_{2}\right)$, and thus $\mathrm{CO}$ itself was not necessarily important. This analysis implies that the reduction in $\mathrm{CO}$ emission does not readily result in a reduction in ozone concentrations if not accompanied by a reduction in emission of other precursors.

\subsubsection{ALD}

PTR-MS showed that the $\mathrm{CH}_{3} \mathrm{CHO}$ concentrations were normally higher than the $\mathrm{HCHO}$ concentrations during the campaign period (1.8 and $3.2 \mathrm{ppb}$ respectively for $\mathrm{HCHO}$ and $\mathrm{CH}_{3} \mathrm{CHO}$ concentrations as midday 6-h averages (09:0015:00 CST)). This magnitude relationship has rarely been reported, and thus it could be another feature specific to the atmospheric composition over China. However, we cannot dismiss the possibility that the ALD signal at $m / z$ of 45 in the PTR-MS was affected by other compounds. Thus, we conducted an additional sensitivity run with the ALD concentration reduced by a factor of 3 . The daily production of ozone reduced to $52 \mathrm{ppb}$ in this run from $58 \mathrm{ppb}$ in the base run. This reduction would be because 1) the initial radical production rate from the photolysis of ALD was reduced, 2) the $\mathrm{OH}+\mathrm{ALD}$ reaction, forming a relatively efficient catalytic cycle of ozone production, slowed, and because 3) PAN formation decreased, making ozone formation inefficient.

\subsubsection{Biogenic hydrocarbons}

The average isoprene and $\Sigma$-monoterpene concentrations observed at midday are 0.28 and $0.19 \mathrm{ppb}$. The observed air mass might have been affected by the emission of biogenic hydrocarbon from nearby trees or the local biosphere on the mountain slopes, over which the air masses have traveled as the daytime upslope wind. The $\mathrm{CO}_{2}$ concentrations measured at the site has a regular daytime drop (nighttime average (21:00-03:00 CST) - daytime average $(09: 00-15: 00$ CST $)=3.8 \mathrm{ppb}$ (Komazaki et al., unpublished data, 2006)), suggesting the possibility that the air mass is influenced by the vegetation. Thus we made an additional sensitivity run in which isoprene and monoterpene concentrations were set to zero to calculate the representative ozone production rate for the altitude level $(1.5 \mathrm{~km})$ without influence from vegetation. In this case, the daily production of ozone decreased to $49 \mathrm{ppb}$ from the $58 \mathrm{ppb}$ of the base run. The analysis suggests that biogenic hydrocarbons make some but limited contribution to ozone production. Thus, we conclude that the determined ozone production rate was mostly representative for the altitude in the middle of CEC, even when the biogenic hydrocarbon concentrations had some variability. 


\subsubsection{Heterogeneous loss of $\mathrm{HO}_{2}$}

Although the heterogeneous loss of $\mathrm{HO}_{2}$ on aerosol surfaces has been suggested in recent studies (e.g., Morita et al., 2004; Taketani et al., 2008), it is rarely incorporated in a model exploring ozone production. The loss rate of $\mathrm{HO}_{2}\left(k_{\gamma}\right)$ was calculated using the following Fuchs-Sutugin equation and incorporated in our box model.

$k_{\gamma}=\int \frac{4 \pi D r}{1+K_{n}\left(\frac{1.333+0.71 K_{n}^{-1}}{1+K_{n}^{-1}}+\frac{4(1-\gamma)}{3 \gamma}\right)} N d r$,

where $K_{n}$ is the Knudsen number, $r$ is the radius of the aerosol, and $N$ is the number density of the particles. The gas phase diffusion coefficient $D$ of $\mathrm{HO}_{2}$ was assumed to be $0.247 \mathrm{~cm}^{2} \mathrm{~s}^{-1}$ (Mozurkewich et al., 1987). The uptake coefficient $\gamma$ employed in this run was the central value in the range of our laboratory measurements, $0.25 \pm 0.09$ $(n=10)$, which were determined using aerosol flow tubechemical conversion-laser-induced fluorescence (Taketani et al., 2008). In the experiment, aerosol particles were generated in an aerosol flow tube in the laboratory by atomizing the water extract of total suspended particles collected on quartz filters (10 samples) using a high-volume sampler during the field campaign. The relative humidity during the laboratory experiment was $75 \pm 2 \%$, close to the campaign average (68\%). Details of the experiments will be described elsewhere (Taketani et al., 2009).

The particle size distribution was not observed during the campaign and thus it was roughly estimated from the summed observed mass concentrations of major chemical species. In detail, the estimation was made separately for 9 size bins segregated at $0.43,0.65,1.1,2.1,3.3,4.7,5.8$, and $9.0 \mu \mathrm{m}$. First, the total mass concentration for each bin, as estimated by adding mass concentrations of water-soluble ions, organics, elemental carbon, and water (assumed as $20 \%$ of dry mass), was converted to volume density by assuming a constant density of particles $\left(1.4 \mathrm{~g} \mathrm{~cm}^{-3}\right)$. In this step, it was assumed that the size distributions of elemental carbon and organic carbon were similar to those of sulfate particles and that the mass concentrations of organic aerosols were 1.6 times the observed OC mass concentration. Next, the volume distribution was converted to a number distribution. For the smallest bin (less than $0.43 \mu \mathrm{m}$ ), a typical size distribution for the "background and aged urban plume case" (accumulation mode diameter $(0.12 \mu \mathrm{m})$ with $\sigma_{g}=1.84$ and coarse mode diameter $(0.83 \mu \mathrm{m})$ with $\left.\sigma_{g}=2.12\right)$ reported by Whitby and Sverdrup (1980) was assumed for converting the volume to a number density distribution. For the other size bins, diameters representative of the bins $(0.5,0.8,1.5,3.0,4.0 .5 .0,6.0$, and $10 \mu \mathrm{m})$ were roughly estimated and used to convert volume to number density. The median number density of particles integrated over the full size range was $4.4 \times 10^{3} \mathrm{~cm}^{-3}$ for 30 filter samples covering the whole campaign period. The typical surface area concentration was $6.3 \times 10^{2} \mu \mathrm{m}^{2} \mathrm{~cm}^{-3}$.
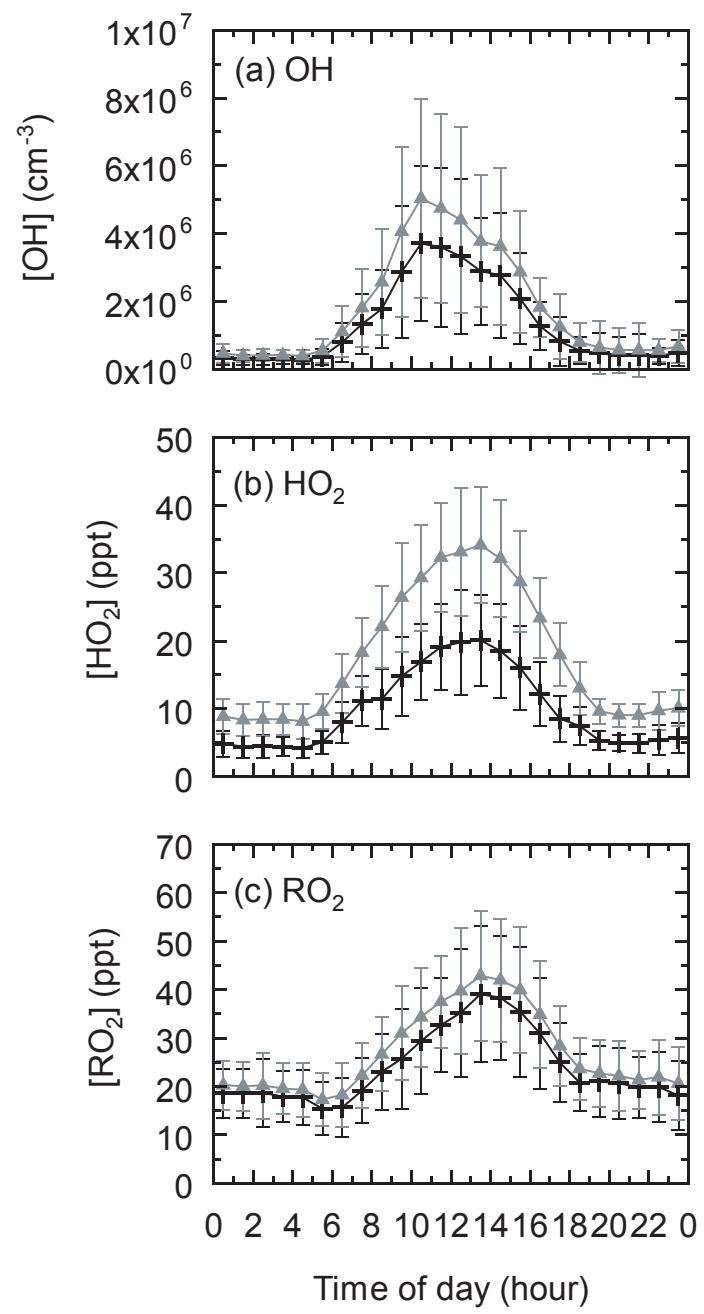

Fig. 8. Average diurnal variations in $\mathrm{OH}, \mathrm{HO}_{2}$, and $\mathrm{RO}_{2}$ concentrations estimated by a photochemical box model for the case without heterogeneous loss of $\mathrm{HO}_{2}$ (gray triangles) and the case with heterogeneous loss of $\mathrm{HO}_{2}$ (crosses).

The median $k_{\gamma}$ value calculated from Eq. (4) using the number density size distributions was $0.014 \mathrm{~s}^{-1}$. Considering that the $\mathrm{HO}_{2}$ loss rate due to self reaction was $8.0 \times 10^{-3} \mathrm{~s}^{-1}$, the heterogeneous loss had a large influence on the $\mathrm{HO}_{2}$ concentration and hence on ozone production.

With this heterogeneous loss of $\mathrm{HO}_{2}$, the daytime maximum $\mathrm{HO}_{2}$ concentration averaged over the campaign period reduced from 34 pptv to 20 pptv (Fig. 8). The $\mathrm{OH}$ and $\mathrm{RO}_{2}$ maximum concentrations also indirectly reduced from 5.0 to $3.7 \times 10^{6} \mathrm{~cm}^{-3}$ and from 43 to $39 \mathrm{pptv}$, respectively. In general, the impact of heterogeneous loss would be large when the $\mathrm{OH}+\mathrm{NO}_{2}+\mathrm{M}$ reaction does not play a significant role in the radical termination reaction. The upper part of the boundary layer in CEC, where the number density of aerosol particles is still high and the role of the $\mathrm{OH}+\mathrm{NO}_{2}+\mathrm{M}$ reaction is limited (Table 2), is one of the regions where the impact of the heterogeneous loss is large. 
The daily production of ozone decreased to $39 \mathrm{ppb}$ from $58 \mathrm{ppb}$ with the inclusion of the heterogeneous loss of $\mathrm{HO}_{2}$. The daytime 6-h average of the net ozone production rate decreased to $4.3 \mathrm{ppbh}^{-1}$ from $6.4 \mathrm{ppbh}^{-1}$ in the base run. However, these values are still large enough to explain the observed buildup of ozone concentration.

Additional model sensitivity runs with the $\mathrm{NO}_{\mathrm{x}}$ or $\mathrm{NMHC}$ concentrations multiplied by a factor of 1.1 in the presence of heterogeneous loss suggested that the main conclusion of this paper (that production is normally $\mathrm{NO}_{\mathrm{x}}$-limited) remains unchanged; that is, inclusion of the heterogeneous loss of $\mathrm{HO}_{2}$ made the situation more $\mathrm{NO}_{\mathrm{x}}$-limited because more $\mathrm{NO}_{\mathrm{x}}$ is needed to increase the radical termination rate of the $\mathrm{OH}+\mathrm{NO}_{2}+\mathrm{M}$ reaction to a level that can compete with the rate of heterogeneous loss of $\mathrm{HO}_{2}$.

It should be noted that this sensitivity analysis is rough because the size distribution of particles was only estimated and because it is assumed that the effect of the ambient aerosol particles is similar to that of the regenerated particles in the laboratory. However, this is the first time to indicate that the heterogeneous loss of $\mathrm{HO}_{2}$ can be very important to the ozone production rate from the kinetic experiments using aerosol particles collected in the ambient atmosphere.

\section{Summary}

The net photochemical production rate of ozone at the top of Mount Tai, China, was estimated using a photochemical box model on the basis of a tropospheric chemistry mechanism constrained by simultaneous measurements of ozone and its precursors. It is estimated that $58 \pm 37 \mathrm{ppb}$ of ozone can be produced in one day, suggesting that the local photochemistry is active and is an important factor controlling ozone concentration. Normally, $\mathrm{NO}_{\mathrm{x}}$-limited ozone production is suggested from sensitivity model runs. Considering that the $\mathrm{NO}_{\mathrm{x}}$ emission is anticipated to increase in CEC at least until 2020 (Ohara et al., 2007), the regional ozone production will become severer in the future. Sensitivity runs indicated that reductions in the concentrations of $\mathrm{CO}$ (to $90 \mathrm{ppb}$ ), $\mathrm{CH}_{3} \mathrm{CHO}$ (by a factor of 3), and biogenic hydrocarbons (to zero) resulted in $0 \%, 10 \%$, and $16 \%$ reductions in the daily production of ozone. Heterogeneous loss of $\mathrm{HO}_{2}$ is potentially important in that it possibly reduces production by $33 \%$. However, the conclusion of there being a $\mathrm{NO}_{\mathrm{x}}$-limited condition did not change with the inclusion of heterogeneous loss.

Acknowledgements. This work was supported by the Global Environment Research Fund (B-051, C-081 and S-7) of the Ministry of the Environment and the Ministry of Education, Culture, Sports, Science and Technology, Japan and a Grant-in-Aid for Scientific Research (KAKENHI) (C) 19510026. Yuesi Wang (Institute of Atmospheric Physics, Chinese Academy of Sciences) is acknowledged for providing data for water soluble chemical species of aerosol particles during the campaign.

Edited by: S. C. Liu

\section{References}

Cantrell, C. A., Shetter, R. E., Gilpin, T. M., Calvert, J. G., Eisele, F. L., and Tanner, D. J.: Peroxy radical concentrations measured and calculated from trace gas measurements in the Mauna Loa Observatory Photochemistry Experiment 2, J. Geophys. Res., 101(D9), 14653-14664, 1996.

Carmichael, G. R., Tang, Y., Kurata, G., Uno, I., Streets, D., Woo, J.-H., Huang, H., Yienger, J., Lefer, B., Shetter, R., Blake, D., Atlas, E., Fied, A., Apel, E., Eisele, F., Cantrell, C., Avery, M., Barrick, J., Sachse, G., Brune, W., Sandholm, S., Kondo, Y., Singh, H., Talbot, R., Bandy, A., Thorton, D., Clarke, A., and Heikes, B.: Regional-scale chemical transport modeling in support of the analysis of observations obtained during the TRACE-P experiment, J. Geophys. Res., 108(D21), 8823, doi:10.1029/2002JD003117, 2003a.

Carmichael, G. R., Tang, Y., Kurata, G., Uno, I., Streets, D. G., Thongboonchoo, N., Woo, J.-H., Guttikunda, S., White, A., Wang, T., Blake, D. R., Atlas, E., Fried, A., Potter, B., Avery, M. A., Sachse, G. W., Sandholm, S. T., Kondo, Y., Talbot, R. W., Bandy, A., Thorton, D., and Clarke, A. D.: Evaluating regional emission estimates using the TRACE-P observations, J. Geophys. Res., 108(D21), 8810, doi:10.1029/2002JD003116, 2003b.

Fischer, H., Kormann, R., Klüpfel, T., Gurk, Ch., Königstedt, R., Parchatka, U., Mühle, J., Rhee, T. S., Brenninkmeijer, C. A. M., Bonasoni, P., and Stohl, A.: Ozone production and trace gas correlations during the June 2000 MINATROC intensive measurement campaign at Mt. Cimone, Atmos. Chem. Phys., 3, 725-738, 2003, http://www.atmos-chem-phys.net/3/725/2003/.

Heard, D. E., Read, K. A., Methven, J., Al-Haider, S., Bloss, W. J., Johnson, G. P., Pilling, M. J., Seakins, P. W., Smith, S. C., Sommariva, R., Stanton, J. C., Still, T. J., Ingham, T., Brooks, B., De Leeuw, G., Jackson, A. V., McQuaid, J. B., Morgan, R., Smith, M. H., Carpenter, L. J., Carslaw, N., Hamilton, J., Hopkins, J. R., Lee, J. D., Lewis, A. C., Purvis, R. M., Wevill, D. J., Brough, N., Green, T., Mills, G., Penkett, S. A., Plane, J. M. C., Saiz-Lopez, A., Worton, D., Monks, P. S., Fleming, Z., Rickard, A. R., Alfarra, M. R., Allan, J. D., Bower, K., Coe, H., Cubison, M., Flynn, M., McFiggans, G., Gallagher, M., Norton, E. G., O’Dowd, C. D., Shillito, J., Topping, D., Vaughan, G., Williams, P., Bitter, M., Ball, S. M., Jones, R. L., Povey, I. M., O’Doherty, S., Simmonds, P. G., Allen, A., Kinnersley, R. P., Beddows, D. C. S., Dall'Osto, M., Harrison, R. M., Donovan, R. J., Heal, M. R., Jennings, S. G., Noone, C., and Spain, G.: The North Atlantic Marine Boundary Layer Experiment(NAMBLEX). Overview of the campaign held at Mace Head, Ireland, in summer 2002, Atmos. Chem. Phys., 6, 2241-2272, 2006, http://www.atmos-chem-phys.net/6/2241/2006/.

Inomata, S., Tanimoto, H., Kameyama, S., Tsunogai, U., Irie, H., Kanaya, Y., and Wang, Z.: Technical Note: Determination of formaldehyde mixing ratios in air with PTR-MS: laboratory experiments and field measurements, Atmos. Chem. Phys., 8, 273 284, 2008, http://www.atmos-chem-phys.net/8/273/2008/.

Inomata, S., Tanimoto, H., Kato, S., Suthawaree, J., Kanaya, Y., Pochanart, P., Liu, Y., and Wang, Z.: PTR-MS measurements of non-methane volatile organic compounds during an intensive field campaign at the summit of Mount Tai, China, in June 2006, Atmos. Chem. Phys. Discuss., in preparation, 2009.

Kanaya, Y., Cao, R., Akimoto, H., Fukuda, M., Komazaki, Y., Yokouchi, Y., Koike, M., Tanimoto, H., Takegawa, N., and 
Kondo Y.: Urban photochemistry in central Tokyo: 1. Observed and modeled $\mathrm{OH}$ and $\mathrm{HO}_{2}$ radical concentrations during the winter and summer of 2004, J. Geophys. Res., 112, D21312, doi:10.1029/2007JD008670, 2007.

Kanaya, Y., Fukuda, M., Akimoto, H., Takegawa, N., Komazaki, Y., Yokouchi, Y., Koike, M., and Kondo, Y.: Urban photochemistry in central Tokyo: 2. Urban photochemistry in central Tokyo: 2. Rates and regimes of oxidant $\left(\mathrm{O}_{3}+\mathrm{NO}_{2}\right)$ production, J. Geophys. Res., 113, D06301, doi:10.1029/2007JD008671, 2008.

Kleinman, L. I., Daum, P. H., Imre, D., Lee, Y.-N., Nunnermacker, L. J., Springston, S. R., Weinstein-Lloyd, J., and Rudolph, J.: Ozone production rate and hydrocarbon reactivity in 5 urban areas: A cause of high ozone concentration in Houston, Geophys. Res. Lett., 29(10), 1467, doi:10.1029/2001GL014569, 2002.

Kleinman, L. I., Daum, P. H., Lee, Y.-N., Nunnermacker, L. J., Springston, S. R., Weinstein-Lloyd, J., and Rudolph, J.: A comparative study of ozone production in five U.S. metropolitan areas, J. Geophys. Res., 110, D02301, doi:10.1029/2004JD005096, 2005.

Li, J., Wang, Z., Akimoto, H., Gao, C., Pochanart, P., and Wang, X.: Modeling study of ozone seasonal cycle in lower troposphere over east Asia, J. Geophys. Res., 112, D22S25, doi:10.1029/2006JD008209, 2007.

Li, J., Wang, Z., Akimoto, H., Yamaji, K., Takigawa, M., Pochanart, P., Liu, Y., Tanimoto, H., and Kanaya, Y.: Near-ground ozone source attributions and outflow in central eastern China during MTX2006, Atmos. Chem. Phys., 8, 7335-7351, 2008a, http://www.atmos-chem-phys.net/8/7335/2008/.

Li, J., Pochanart, P., Wang, Z., Liu, Y., Yamaji, K., Takigawa, M., Kanaya, Y., and Akimoto, H.: Impact of chemical production and transport of summertime diurnal ozone behavior at a mountainous site in North China Plain, SOLA, 4, 121-124, $2008 \mathrm{~b}$.

Luo, C., St. John, J. C., Xiuji, Z., Lam, K. S., Wang, T., and Chameides, W. L.: A nonurban ozone air pollution episode over eastern China: Observations and model simulations, J. Geophys. Res., 105(D2), 1889-1908, 2000.

Martin, R. V., Fiore, A. M., and Van Donkelaar, A.: Space-based diagnosis of surface ozone sensitivity to anthropogenic emissions, Geophys. Res. Lett., 31, L06120, doi:10.1029/2004GL019416, 2004.

Morita, A., Kanaya, Y., and Francisco, J. S.: Uptake of the $\mathrm{HO}_{2}$ radical by water: Molecular dynamics calculations and their implications for atmospheric modeling, J. Geophys. Res., 109, D09201, doi:10.1029/2003JD004240, 2004.

Mozurkewich, M., McMurry, P. H., Gupta, A., and Calvert, J. G.: Mass accommodation coefficient of $\mathrm{HO}_{2}$ on aqueous particles, J. Geophys. Res., 92(D4), 4163-4170, 1987.

Ohara, T., Akimoto, H., Kurokawa, J., Horii, N., Yamaji, K., Yan, X., and Hayasaka, T.: An Asian emission inventory of anthropogenic emission sources for the period 1980-2020, Atmos. Chem. Phys., 7, 4419-4444, 2007,

http://www.atmos-chem-phys.net/7/4419/2007/.

Parker, A. E., Monks, P. S., Wyche, K. P., Balzani-Lööv, J. M., Staehelin, J., Reimann, S., Legreid, G., Vollmer, M. K., and Steinbacher, M.: Peroxy radicals in the summer free troposphere: seasonality and potential for heterogeneous loss, Atmos. Chem. Phys., 9, 1989-2006, 2009,

http://www.atmos-chem-phys.net/9/1989/2009/.
Pochanart, P. Kanaya, Y., Jie, L., Komazaki, Y., Akimoto, H., Liu, Y., Wang, X., and Wang. Z.: Surface ozone, carbon monoxide and black carbon over Central East China during MTX2006, Atmos. Chem. Phys. Discuss., in preparation, 2009.

Sillman, S.: The relation between ozone, NOx and hydrocarbons in urban and polluted rural environments, Atmos. Environ., 33, 1821-1845, 1999.

Stockwell, W. R., Kirchner, F., Kuhn, M., and Seefeld, S.: A new mechanism for regional atmospheric chemistry modeling, J. Geophys. Res., 102(D22), 25847-25880, 1997.

Streets, D. G., Bond, T. C., Carmichael, G. R., Fernandes, S. D., Fu, Q., He, D., Klimont, Z., Nelson, S. M., Tsai, N. Y., Wang, M. Q., Woo, J.-H., and Yarber, K. F.: An inventory of gaseous and primary aerosol emissions in Asia in the year 2000, J. Geophys. Res., 108(D21), 8809, doi:10.1029/2002JD003093, 2003.

Suthawaree, J., Kato, S., Okuzawa, K., Kanaya, Y., Pochanart, P., Akimoto, H., Wang, Z., and Kajii, Y.: Measurements of volatile organic compounds in the middle of Central East China during Mount Tai Experiment 2006 (MTX2006): observation of regional background and impact of biomass burning, Atmos. Chem. Phys. Discuss., 9, 16715-16753, 2009,

http://www.atmos-chem-phys-discuss.net/9/16715/2009/.

Taketani, F., Kanaya, Y., and Akimoto, H.: Kinetics of heterogeneous reaction of $\mathrm{HO}_{2}$ radical at ambient concentration levels with $\left(\mathrm{NH}_{4}\right)_{2} \mathrm{SO}_{4}$ and $\mathrm{NaCl}$ aerosol particles, J. Phys. Chem. A, 112(11), 2370-2377, doi:10.1021/jp0769936, 2008.

Taketani, F., Kanaya, Y., Pochanart, P., Liu, Y., Li, J., Akimoto, H., Okuzawa, K., Kawamura, K., and Wang, Z.: Measurement of uptake coefficients of $\mathrm{HO}_{2}$ radical with sampled aerosol particles in the ambient air, Atmos. Environ., in preparation, 2009.

Wang, Z., Li, J., Wang, X., Pochanart, P., and Akimoto, H.: Modeling of Regional High Ozone Episode Observed at Two Mountain Sites (Mt. Tai and Huang) in East China, J Atmos. Chem., 55, 253-272, 2006.

Whitby, K. T. and Sverdrup, G. M.: California aerosols: Their physical and chemical characteristics, Adv. Environ. Sci. Technol., 9, 477-517, 1980.

Yamaji, K., Ohara, T., Uno, I., Kurokawa, J., Pochanart, P., and Akimoto, H.: Future prediction of surface ozone over east Asia using Models-3 Community Multiscale Air Quality Modeling System and Regional Emission Inventory in Asia, J. Geophys. Res., 113, D08306, doi:10.1029/2007JD008663, 2008.

Zanis, P., Monks, P. S., Green, T. J., Schuepbach, E., Carpenter, L. J., Mills, G. P., Rickard, A. R., Brough, N., and Penkett, S. A.: Seasonal variation of peroxy radicals in the lower free troposphere based on observations from the FREE Tropospheric EXperiments in the Swiss Alps, Geophys. Res. Lett., 30(10), 1497, doi:10.1029/2003GL017122, 2003.

Zhu, B., Akimoto, H., Wang, Z., Sudo, K., Tang, J., and Uno, I.: Why does surface ozone peak in summertime at Waliguan?, Geophys. Res. Lett., 31, L17104, doi:10.1029/2004GL020609, 2004. 